\title{
ISLAMIC DA'WAH IN THE MALAY PENINSULA: CONTRIBUTIONS OF THE SAYYIDS OF EARLY TIMES
}

\author{
Ahmad Fauzi Abdul Hamid \\ Universiti Sains Malaysia, Malaysia \\ E-mail: afauzi@usm.my \\ Shaikh Abdullah Hassan Mydin \\ Universiti Sains Malaysia, Malaysia \\ E-mail: abdullah@usm.my
}

\begin{abstract}
This article traces the stellar accomplishments of the Sayyids, as descendants of the Prophet Muhammad are known in the field of Islamic da'wah. For the many Sayyids who excelled as torchbearers of Islam in the Malay world, propagating Islam was a lifetime vocation that passed without the stress that we find in the modern world. Their da'wah efforts encompassed such diverse undertakings as employing business acumen in confronting the challenges of colonialism and Malay court culture, immersing themselves in native communities via intermarriages and adoption of local customs, and carving a niche for themselves in local and international politics as advisors and emissaries. At grassroots level, da'wah for them was inseparable from daily chores and mundane affairs. That Western colonialism hardly made any impact in directly desacralizing the Malays is a tribute to the success of the Sayyids' da'wah efforts, which served as a buffer against the religious implications of colonial encroachment into autochthonous institutions and lifestyle. By looking at some examples of how the Sayyids interacted with local communities in selected regions of the Malay world, this article traces part of this glittering history of da'wah in the easternmost parts of the Islamic commonwealth. Most importantly, the Malay world's Islamization was distinguished by lack of violence and emphasis on educational progress more than anything else.
\end{abstract}

Keywords: Sayyid; Hadrami; Islamic da'wah; Malay world; Islamization.

Article history: Received: 12 February 2020 | Revised: 21 March 2021 Accapted: 04 May 2021 | Available online: 01 June 2021

\section{How to cite this article:}

Abdul Hamid, Ahmad Fauzi, and Shaikh Abdullah Hassan Mydin. "Islamic Da'wah in the Malay Peninsula: Contributions of the Sayyids of Early Times". Teosofi: Jurnal Tasawuf dan Pemikiran Islam 11, no. 1 (2021): 46-70. https://doi.org/10.15642/teosofi.2021.11.1.46-70 


\section{Introduction}

It is a commonplace in the Muslim world for descendants of the Holy Prophet Muhammad to be generally given the honorific title of Sayyid - a designation conventionally attached in front of one's given name, provided that their pedigrees are established from credible genealogical sources. Etymologically, the term Sayyid carries several meanings derived from its original Arabic: leader, tribal chief, noble, and sir. Traditionally, Sayyid is treated synonymously, genealogical variation notwithstanding, with Sharif - the honorable one, and Habib - the loved one. ${ }^{1}$ Female descendants of Sayyids are known as Sharifah or Sayyidah. ${ }^{2}$ As for Arabs who do not share lineage with the Prophet Muhammad, titles that reflect social status in their Middle Eastern homelands are frequently attached to their names.

Social groups other than the 'Sädāh - plural of Sayyid, include the Mashayikh — plural of Shaykh, referring to an elderly or knowledgeable person; the Qaba'il-plural of Qabilah or 'tribal people,' and Masäkin-plural of miskin, i.e., the poor. To Arab migrants in the Malay world, however, the distinction between the Sädah and the 'non-Sa'da' has been the most important social stratification ${ }^{3}$ Besides the distinctive attachment of the titles of Sayyid and Sharifah to their given names, Sayyids are also distinguished by the wide usage of family surnames such as al-Aț̣āas, al-Junayd, al-Jufrī, al-Aidid, alShahabuddin, al-Kaff, al-Saqqāf, al-Jamalullail, al-Habshī, and al'Idrūs. ${ }^{4}$

Islamization of the Malay world-a vast region spanning present-day Malaysia, Indonesia, Brunei, Singapore, southern Thailand, southern Philippines, and southern Cambodia, i.e., areas

1 In this article, the spelling 'Sayyid', commonly used at international level is preferred over its Malay variant - 'Syed'. Other variants to distinguish the noble rank include Sharif, Sayid, Sayyidi, Saidi, Sayyidinā, and Saidinā. The final two terms are normally reserved for contemporaries of the Prophet Muhammad, and are also used to address the Prophet when reciting salawat (salutation) to him.

${ }^{2}$ Mahayudin Haji Yahaya, "Latarbelakang Sejarah Keturunan Sayid di Malaysia," in Khoo Kay Kim (ed.), Tamadun Islam di Malaysia (Kuala Lumpur: Persatuan Sejarah Malaysia, 1980), 60-61.

3 Omar Farouk Bajunid, "The Arabs in Southeast Asia: A Preliminary Overview," Hiroshima Journal of International Studies 8 (1996), 26.

4 Mohammad Redzuan Othman, "The Arabs Migration and Its Importance in the Historical Development of the Late Nineteenth and Early Twentieth Century Malaya," paper presented at the $15^{\text {th }}$ Annual Conference of the World History Association, California State University, Los Angeles, USA, 22-25 June 2006, 5. 
that used any variant of the Malay-Indonesian language as their lingua franca, was one of the greatest success stories of da'wah (propagation) from the center of medieval Islamic civilization in the Middle East to its periphery. So important has the process of da'wah been to MalayMuslim society that when Islamic resurgence spread to Southeast Asia in the 1970s and 1980s, the religious revival became known locally as the $d a^{6} w a b^{5}$ phenomenon. Groups involved in the reassertion of Islam were popularised as da'wah movements, and their activists acquired the tag of da'wah people'. While various theories on the provenance and modalities of the Islamization of the Malay world exist and continue to engender debate among scholars, ${ }^{7}$ the pivotal role played by Sayyids has been underlined by the region's foremost Islamic philosopher, Syed Naguib Al-Attas: “.... the earliest missionaries of Islam in the Malay Archipelago and those who came after from the 12 to the 16 centuries were Arabs. There are rational processes that can be verified by empirical facts showing that the early missionaries who introduced and disseminated Islam and established Islamic kingdoms in the Malay Archipelago were Arabs (sayyids) who came from Saudi Arabia".

The ancestors of Sayyids presently domiciled in Southeast Asia had moved to the Malay world in a gradual trans-continental migration process spanning at least seven centuries. The majority of

5 The Malay language cognate of da'wah.

${ }^{6}$ Judith A. Nagata, The Reflowering of Malaysian Islam: Modern Religious Radicals and their Roots (Vancouver: University of British Columbia Press, 1984), 81-87; Zainah Anwar, Islamic Revivalism in Malaysia: Dakwah among the Students (Petaling Jaya: Pelanduk Publications, 1987); Sharifah Zaleha binti Syed Hassan, "Negotiating Islamism: The Experiences of the Muslim Youth Movement of Malaysia," Journal for Islamic Studies 29 (2009), 65.

7 Cf. S.Q. Fatimi, Islam Comes to Malaysia (edited by Shirle Gordon) (Singapore: Malaysian Sociological Research Institute, 1963); Syed Hussein Alatas, "On the Need for an Historical Study of Malaysian Islamisation," Journal of Southeast Asian History 4, no. 3 (1963), 62-74; Paul Coatalen, "The Coming of Islam to S.E. Asia: A Critical Review of Some Extant Theories," The Islamic Quarterly XXV, nos. 3-4 (1981), 100-121; Syed Farid Alatas, "Notes on Various Theories Regarding the Islamisation of the Malay Archipelago," The Muslim World LXXV, nos. 3-4 (1985), 162-175; Anthony H. Johns, "Islamisation in Southeast Asia: Reflections and Reconsiderations with Special Reference to the Role of Sufism," Southeast Asian Studies 31, no. 1 (1993), 43-61; Ahmad Fauzi Abdul Hamid, "The Impact of Sufism on Muslims in Pre-colonial Malaysia: An Overview of Interpretations," Islamic Studies 41, no. 3 (2002), 467-493.

8 Syed Muhammad Naquib al-Attas, Historical Fact and Fiction (Johor Bahru: Universiti Teknologi Malaysia Press, 2012), 135. 
them trace their roots to the Hadramaut region in present-day Yemen to the south of the Rub al-Khali desert in what is today Saudi Arabia. Referred to in the Bible as 'Hazamaweth', Hadramaut is an arid valley surrounded by desert, with a civilizational history predating the epoch of the Prophet Muhammad, as emphasized by the presence of many tombs of past Messengers of God and saints. Hadramis—as people who originate from Hadramaut are known-are generally proud of the purity of their Arab blood. Their Arabic language accent has long been regarded as best resembling the Quranic dialect. Tarim, the district from where most Southeast Asian Sayyids locate their roots, has long distinguished itself as a prominent center of Islamic learning which hosted the missionary activities of such distinguished companions of the Prophet Muhammad as 'Alī b. Abī Țâlib, Mu'ādh b. Jabal, Abū Mūsā al-Ash'arī, and Khālid al-Walīd.'

Hadrami Sayyids are also called the $\mathrm{Ba}$ 'Alawis, as the descendants of 'Ali bin 'Alawi, who emigrated to Tarim $521 \mathrm{H} / 1127 \mathrm{AD}$., are referred to. 'Ali bin 'Alawi's direct ancestor, Ahmad bin Isa al-Muhajir, was the tenth descendant of the Prophet Muhammad through the lineage of his grandson, Sayyidinā Husayn, son of 'Alī b. Abī Ṭālib and Fātimah bint Muhammad. Ḥusayn was tragically killed by the army of the second Umayyad caliph Yazid bin Mu'āwiyah in Karbala, Iraq, in 61H./680AD. Escaping from 'Abbasid persecution, Ahmad bin Isa migrated from Basra to Hadramaut in 317H./929AD. Identification of the Prophet Muhammad's family tree became difficult as a result of constant relocation of his descendants and uprooting of communities. Hadrami Sayyids' claims to prophetic pedigree were nevertheless verified in Mecca's historic occasion, acknowledged by then scholars of genealogy and approved by the pilgrims.

Since the large-scale migration of the Ba'alawis to Tarim, 'Alawi Sayyids have regarded the preservation of their lineage as very important. Based on the view that the family blood is carried by the male offspring which inherits the family name, family elders have sought, somewhat controversially, to institutionalize the doctrine of kafäab (appositeness), which allows a male Sayyid to marry a nonSyarifah woman, but not otherwise. However, their hierarchical

9 Abdul Qadir Umar Mauladdawilah, Tarim: Kota Sejuta Wali (Kuala Lumpur: InTeam Publishing, 2014); Yahaya, "Latarbelakang Sejarah Keturunan Sayid di Malaysia," 61; Bajunid, "The Arabs in Southeast Asia: A Preliminary Overview," 28. 
notion of society was no hindrance to 'Alawi Sayyids distinguishing themselves in religious sciences, especially as masters of Islamic spirituality or Sufism. In the 7 H./13AD. century, Sayyid 'Alawi bin Muhammad al-Faqih al-Muqaddam founded the "Alawiyya sufi order, ${ }^{10}$ which until today maintains an operational center in the Ba'alawi Mosque, Singapore. Among the many tariqabs (sufi orders) which spread their wings throughout the Malay world, the 'Alawiyya's practices of ratib and dhiker (remembrances of God) were distinctively characterized by veneration of the awliy a' (saints) and their karamah (miracles). ${ }^{11}$ However, spiritual practices of the Sayyids were not restricted to the "Alawiyya tariqah. A brief survey of the spiritual genealogy of authentic tariqabs reveals that a majority of its founders and pioneers were Sayyids. ${ }^{12}$

\section{The Movement of Hadrami Sayyids from the Middle East to the Malay World}

Available evidence allows us to extrapolate that the large-scale migration of Hadrami Sayyids from the Middle East to the Malay world may have been foretold by the Prophet Muhammad. A hadīth related by Ibn Mājah, al-Tirmīdhī, and Abū Dāwud, for example, reads:

"Whilst we were with the Prophet (peace be upon him), some young men from Bani Hashim approached us. When the Prophet (peace be upon him) saw them, his eyes filled with tears and the color of his face changed. I said, 'We can see something has changed in your face, and it upsets us'. The Prophet said, we are the people of a Household for whom Allah has chosen the Hereafter rather than this world. The people of my Household (Abl al-Bayt) will suffer a great deal after my death, and will be persecuted until a people carrying black banners will come out of the east. They will instruct the people to do good, but the people will refuse, they will fight

\footnotetext{
${ }^{10}$ Syed Farid Alatas, S.F. "The Tariqat al-'Alawiyyah and the Emergence of the Shi'i School in Indonesia and Malaysia," Oriente Moderno, XVIII(LXXIX) (1999), 328-329.

${ }^{11}$ Yahaya, "Latarbelakang Sejarah Keturunan Sayid di Malaysia," 62-69; Wan Mohd. Shaghir Abdullah, Penyebaran Thariqat-thariqat Shufiyah Mu'tabarah di Dunia Melayu (Kuala Lumpur: Khazanah Fathaniyah, 2000), 93-95.

12 Syed Naguib al-Attas, Some Aspects of Sufism as Understood and Practised among the Malays (edited by Shirle Gordon) (Singapore: Malaysian Sociological Research Institute, 1963), 32; Abdullah, Penyebaran Thariqat-thariqat Shufiyah Mu'tabarah di Dunia Melayu, passim.
} 
until they are victorious, and the people do as they asked, but they will not accept it from them until they hand over power to a man from my household Then the earth will be filled with fairness, just as it had been filled with injustice. If any of you live to see this, you should go to him even if you have to crawl over ice." 13

In relation to the history of the Prophet's progenies, otherwise known as Abl al-Bayt (members of the Prophet's household), the above hadìth prognosticates three phases of banishment leading to their large-scale migration out of Arabia. First, emigration in response to the persecution they suffered at the hands of the Abbasid caliphs al-Mu'tamid (256-276H./870-892AD.) and al-Muqtadir (295-320H./ 908-932AD.). Relocating from Medina to Basra and then from Basra to Hadramaut, the Abl al-Bayt attempted to return to the Hijaz-the region which hosts the holy cities of Mecca and Medina, under the leadership of Ahmad bin 'Isa al-Muhajir in 318H./930AD., without avail. ${ }^{14}$

Second, emigration ensued from Baghdad's Mongol invasion in 1258AD, which tragically ended the Abbasid dynasty. As a consequence, ulama (religious scholars) were forced to seek new havens outside the Middle Eastern Islamic heartlands. The fall of Baghdad unwittingly unleashed novel missionary efforts helmed by the same generation of ulama, many of whom were members of the Abl al-Bayt. Unexplored and fertile, the eastern world immediately became their favorite destination. ${ }^{15}$ This Arab exodus corresponds in time with the scholarly consensus that Islam took hold in the Malay world from the end of the thirteenth century. ${ }^{16}$ This mass movement represented the first wave of the arrival of Hadrami Sayyids to the Malay world.

The downfall of Baghdad shifted the center of Muslim trade and commerce to the port city of Aden, to the south of Hadramaut.

\footnotetext{
13 Ibn Kathir, The Signs before the Day of Judgement (translated by Huda Khattab) (London: Dar Al Taqwa, 1991), 22-23.

14 Yahaya, "Latarbelakang Sejarah Keturunan Sayid di Malaysia," 62; (Tun) Suzana (Tun) $\mathrm{Hj}$ Othman and $\mathrm{Hj}$ Muzaffar Dato' Hj Mohamad, Ablul-Bait (Keluarga) Rasulullah SAW \& Kesultanan Melayu (Batu Caves: Crescent News, 2006), 117-118.

15 G.E. Marrison, "The Coming of Islam to the East Indies," Journal of the Malayan Branch of the Royal Asiatic Society XXIV, no. 1 (1951), 28.

16 Alatas, "Notes on Various Theories Regarding the Islamisation of the Malay Archipelago," 162; Ahmad Fauzi, "The Impact of Sufism on Muslims in Precolonial Malaysia: An Overview of Interpretations," 469.
} 
Aden flourished with eastern goods and assumed the role of the transit point for Arab seafarers heading for the far east. The blossoming of Aden was recorded and by contemporary voyagers such as Ibn Battuta (1304-1369AD.) and Marco Polo (12541324AD). ${ }^{17}$ The apex of the first wave of the coming of Sayyids was reached during the Malaccan Sultanate, whose sovereign wondrously converted to Islam at the hands of one Sayyid Abdul Aziz who hailed from Jeddah. Sayyid Abdul Aziz's descendants later played pivotal roles in the Malaccan court as regal advisors and tutors, extending to the reigns of Sultans Mansur Syah (1456-1477AD.) and Mahmud Syah (1488-1511AD.), both of whom developed great fondness of ulama and sufis. ${ }^{18}$

At its peak, Malacca emerged as the golden center of Islamic education and the launching pad for Islamic da'wah in Southeast Asia. Two Sayyid figures who were immortalized in Javanese folklore as part of its legendary Walisongo (Nine Saints), Sunan Bonang and Sunan Giri, were trained in Malacca by Syeikh Wali Lanang. ${ }^{19}$ The Malaccan Sultanate's international relations were also influenced by the Abl al-Bayt network of Admiral Cheng Ho, the Chinese Ming Dynasty's (1368-1628AD.) envoy to Malacca, who was not only a Muslim but also a $37^{\text {th }}$ descendant of the Prophet Muhammad. Overall, Cheng Ho completed seven voyages covering the Malay states, reaching even Mecca and Medina. Chinese protection over Malacca became a buffer against threats by the Buddhist Siamese kingdom and the Hindu Javanese Majapahit empire. ${ }^{20}$

The third phase of the Hadrami Sayyids' exodus into the eastern lands was intimately connected to the ascendancy of the Nejdi puritanical reformer Muḥammad bin 'Abd al-Wahhāb's (17031792AD.) movement in the Arabian Peninsula. This so-called

\footnotetext{
17 Yahaya, "Latarbelakang Sejarah Keturunan Sayid di Malaysia," 70; Othman, "The Arabs Migration and Its Importance in the Historical Development of the Late Nineteenth and Early Twentieth Century Malaya," 2.

18 Abdullah Ishak, Pendidikan Islam dan Pengarubnya di Malaysia (Kuala Lumpur: Dewan Bahasa dan Pustaka, 1995), 128-129; Suzana and Muzaffar, Ablul-Bait (Keluarga) Rasulullab SAW \& Kesultanan Melayu, 101-104.

${ }^{19}$ Osman Bakar, "Sufism in the Malay-Indonesian World," in Seyyed Hossein Nasr (ed.), Islamic Spirituality: Manifestations (London: SCM Press, 1991), 266-267; Suzana and Muzaffar, Ablul-Bait (Keluarga) Rasulullah SAW \& Kesultanan Melayu, 130-132.

${ }^{20}$ Kong Yuanzhi, Pelayaran Zheng He dan Alam Melayu (Bangi: Penerbit Universiti Kebangsaan Malaysia, 2000); Suzana and Muzaffar, Ablul-Bait (Keluarga) Rasulullah SAW \& Kesultanan Melayu, 105-108.
} 
Wahhabi advance culminated in the establishment of the Saudi Arabian state under 'Abd al-'Azīz bin Sa'ūd in 1926. Wahhabi reformation railed against sufi practices of the Hadrami Sayyids, now being widely accused of practicing bid'ah dalalah (abhorred innovations). British intervention further muddled Hadramaut's internal politics, effectively consolidating the Wahhabis' hold over the Hijaz. It was ultimately inter-Muslim rivalry that triggered the largescale advent of Savvids to the Malay world, as foreseen in the abovequoted hadith, which also foretells that the Abl al-Bayt would gain protection from 'people of the east'. ${ }^{21}$

The chronological account above does not mean that Hadrami Sayyids in the Malay world began only after the entrenchment of Wahhabi hegemony in the Arabian Peninsula. In fact, Chinese sources had recorded the existence of an Arab settlement in Palembang, eastern Sumatera as early as $674 \mathrm{AD} .{ }^{22}$ It was in this year as well that Mu'āwiyah bin Abū Sufyān, founder of the Umayyad dynasty who also established the first Muslim navy, was believed to have outlined a plan, which was eventually abandoned, to conquer the Malay world. ${ }^{23}$ Although Mu'āwiyah's hopes were never fulfilled, the Umayyad era witnessed active Arab exploration of the oceans, motivated by both trade and da'wah.

Dominions under Islamic rule greatly expanded in size even when many companions of the Prophet Muhammad were still alive. Some of them were believed to have left Arabia out of a desire to remain neutral during the recurrent crises which pitted the companions against one another in opposing political camps. Foremost among the intra-Muslim conflicts were the battle of the Camel in Basra in 656AD between the forces of the Prophet's son-inlaw 'Alī bin Abī Ṭālib and the Prophet's wife 'Āisyah bint Abū Bakr, and the Battle of Siffin in Syria in 657AD. between 'Alī and Mu'āwiyah. The greatest tragedy, though, which befell the ummab was undoubtedly the grisly slaughtering of 'Alī's son, Husayn, in Karbala, Iraq, in 680AD., at the hands of the Caliph Yazīd, Mu'āwiyah's soncum-successor. This Karbala tragedy has been immortalized in ritual

\footnotetext{
21 Yahaya, "Latarbelakang Sejarah Keturunan Sayid di Malaysia," 72-73; Suzana and Muzaffar, Ablul-Bait (Keluarga) Rasulullab SAW \& Kesultanan Melayu, 119-120.

22 Syed Naguib al-Attas, Preliminary Statement on a General Theory of the Islamisation of the Malay-Indonesian Archipelago (Kuala Lumpur: Dewan Bahasa dan Pustaka, 1969), 11.

${ }^{23}$ Fatimi, Islam Comes to Malaysia, 69.
} 
ceremonies of the Shicite sect, but the mainstream Sunnis, particularly the Abl al-Bayt, are no less inspired by the valor and martyrdom of Husayn. ${ }^{24}$

During the 'Abbasid caliphate (750-1258AD.), maritime trade became the major means of communication between the Arab and Malay worlds. As the Mongols gradually established firm control over land transportation, the utility of the sea in connecting the Arabs with the Indian sub-continent and the Malay world, famous for its spices, increased manifold. ${ }^{25}$ Following the expulsion of Arabs and Persians from Canton, China, in $877 \mathrm{AD}$, they ended up establishing a colony in a port-city named Kalah, which historians have variously identified as present-day Kedah or Kelang in Peninsular Malaysia or Takuapa in southern Thailand. ${ }^{26}$ It is therefore possible to imagine the existence of scattered Arab Muslim coastal settlements in the Malay archipelago since the ninth century. But the thirteenth century, following the fall of Baghdad, saw new forces unleashing Arab migration to the far cast. The sea traders also wore the badges of sufi da $\mathrm{is}_{\mathrm{s}}{ }^{27}$

Many of the sufi trading guilds were led by Sayyids, who came directly from Arabia or via India, where Sayyids were known to have based themselves for generations. The majority of Sayyids who relocated to Kedah and Penang at the north of the Malay Peninsula, for example, included the Indonesian regions of Palembang and Aceh as part of their itinerary. ${ }^{28}$ Not a few Western scholars thought that Southeast Asian Islam's diverse origins had syncretically watered

${ }^{24}$ Cf. Syed Farid Alatas, Al-Husain bin Ali r.a. sebagai Sumber Ciri-ciri Manusia Baru (Singapore: Masjid Ba'alwi, 2009).

25 G.R. Tibbetts, "Early Muslim Traders in South-East Asia," Journal of the Malayan Branch of the Royal Asiatic Society XXX, no. 1 (1957), 5-6.

26 Tibbetts, "Early Muslim Traders in South-East Asia," 14-17; Al-Attas, Preliminary Statement on a General Theory of the Islamisation of the Malay-Indonesian Archipelago, 11; Othman, "The Arabs Migration and Its Importance in the Historical Development of the Late Nineteenth and Early Twentieth Century Malaya," 6.

27 A.H. Johns, "Sufism as a Category in Indonesian Literature and History," Journal of Southeast Asian History 2, no. 2 (1961), 14; A.H. Johns, "The Role of Sufism in the Spread of Islam to Malaya and Indonesia," Journal of the Pakistan Historical Society 9, no. 3 (1961), 146.

28 Sharifah Zaleha Syed Hassan, "History and Indigenization of the Arabs in Kedah," Asian Journal of Social Science 32, no. 3 (2004), 407; Abdur-Razzaq Lubis, "Traders, Teachers, Pressmen and Pilgrim Brokers: Penang Arabs in the Regional Network," paper presented at the Conference 'Rihlah - Arabs in Southeast Asia', National Library, Singapore, 10-11 April 2011, 4. 
down its authenticity, owing to its mixing with local customs and traditions of peoples of areas which it passed through. Syed Naguib al-Attas, however, has strongly refuted such a contention-based on his research of medieval Malay-Muslim manuscripts. ${ }^{29}$

In reality, the Sayyids were applying hikmah, al-mawizah alhasanah and mujädalah bi al-lati hiya aḥsan in their da'wah efforts so as to avoid unwarranted confrontation with embedded structures of MalayIndonesian society, steeped in the Hindu-Buddhist tradition of their pre-Islamic kingdoms. Far from establishing exclusive communities, which they could have done through their economic prowess and religious standing, the Sayyids, fresh from their experience of harassment in the Middle East, stooped to become part of the host community. It was only via such indigenization that the Sayyids were able to propagate and teach Islam to the newly Islamised Malays, a process cemented through strategic inter-marriages.

Indigenization, however, did not become a barrier for their descendants to migrate further should opportunities of dawah to more distant communities arise. Arabs in general and Sayyids in particular have been inculcated with a moving culture, inheriting a "passion for movement. ${ }^{30}$ Besides assimilating with the local Malay community, Arab migrants guided their Malay brethren in business and trade. Excellence in economic matters was motivated by an emigrant spirit said to be prevalent among Arab diasporic leaders, many of whom were Sayyids. ${ }^{31}$ Sayyids, in addition, were stimulated by their religious conviction that Islam encouraged economic activism, as inherited from the example of the Prophet Muhammad and his companions, many of whom were successful merchants and traders who donated a large part of their wealth to advance the cause of Islam. There was a period during colonial times when the economy of Hadramaut was actually thriving largely from remittances from the Arab diaspora of the Malay world. ${ }^{32}$ Sayyids assimilated into Malay

29 Al-Attas, Preliminary Statement on a General Theory of the Islamisation of the MalayIndonesian Archipelago, 25.

${ }^{30}$ Bajunid, "The Arabs in Southeast Asia: A Preliminary Overview," 27.

31 Syed Hussein Alatas, "The Weber Thesis and South East Asia," Archives De Sociologie Des Religions 15 (1963), 31-33.

32 Joseph Kostiner, "The Impact of Hadrami Emigrants in the East Indies on Islamic Modernism and Social Change in the Hadramawt during the $20^{\text {th }}$ Century', in Raphael Israeli and Anthony H. Johns (eds.), Islam in Asia: Volume II Southeast 
society to such an extent that Malay became a primary language of Islamic instruction in the various Islamic educational institutions which they sponsored throughout Southeast Asia.

\section{Da'wah, Politics, and Economics: Role of Sayyids in Facing the Challenge of Western Colonialism in Selected Malay States}

In the colonial-era nineteenth century and early twentiethcentury Malay politics, Sayyids distinguished themselves as masters in the art of mediation in local governance and international relations. They became close advisors of the Malay sultans, many of whom also went to the extent of taking them as sons-in-law and eventual successors to the throne. Such counseling and companionship were invaluable in the days when the onset of Western imperialism was beginning to penetrate the political, economic, and social lives of the ruling elites, thus posing a grave challenge to the Malay state's integrity. Malay political culture was inexorably tied to the monarchical system, as reflected by the translation of the word 'government' as 'kerajaan' into Malay - a cognate of the word 'raja', meaning 'king'.

Anthropologist Shamsul Amri Baharuddin has identified language, king and religion as three pillars that define Malay identity. ${ }^{33}$ By mastering the three foundations of Malayness and strategically inter-marrying into Malay noblemen's families, Sayyids were not only indigenized but also emerged as putative representatives of the Malays in diplomatic matters. A caveat is in order, however. While generally making an immense contribution towards the rise of nationalism among the native Malays, the Sayyids' response to colonialism was far from monolithic. As much as their clannish affiliations varied widely, their responses to colonial and capitalist encroachment also lacked uniformity. In the western Malayan states of Selangor and Negeri Sembilan for example, different Sayyid families were involved in civil wars on opposing sides, giving rise to British intervention in the

Asia and East Asia (Jerusalem: The Magnes Press, 1984), 211; Bajunid, "The Arabs in Southeast Asia: A Preliminary Overview," 29.

33 A.B. Shamsul, "A History of an Identity, an Identity of a History: The Idea and Practice of 'Malayness' in Malaysia Reconsidered," Journal of Southeast Asian Studies 32, no. 3 (2001), 357, 361-362. 
administration of Malay states. ${ }^{34}$ However diverse though their actions might have been, the reputation of Sayyids as "good people" hailing from families of good birth remained intact to the Malays. ${ }^{35}$

In Kedah, beginning with the arrival of Syeikh Abdul Jalil alMahdani from Palembang to advise and guide Sultan Muhammad Jiwa (reigned 1710-1778AD.), Arabs exerted significant influence over local politics. The al-Jamalullail, al-Shahabuddin, and al-Aidid families began residing in Kedah shortly after Syeikh Abdul Jalil's arrival. Sayyid Harun Jamalullail, a second-generation Arab migrant, was granted the Arau district by the Sultan of Kedah in 1797AD. His son Sayyid Hussain Jamalullail assumed the throne of the new state of Perlis in 1843AD as a gift for having successfully negotiated Kedah's continued sovereignty in the aftermath of the Kedah-Siamese war. ${ }^{36}$

Arab-Malay luminaries figured prominently throughout the hostilities, which broke out in 1824AD. The Kedah army, for instance, was led by one Sayyid Zainal Abidin, better known as Tunku Kudin, who was the Sultan's nephew. Battling alongside him until martyred was Syeikh Abdul Samad al-Palembani, a prominent scholar, translator of Imam al-Ghazālī's treatizes into Malay and son of Syeikh Abdul Jalil al-Mahdani. ${ }^{37}$ During the reign of Sultan Abdul Hamid Halim Syah (1882-1942AD.), the political clout of the Sayyids reached an apogee, as signified by prevalent marriages between Sayyids and the Kedah royalty. Sultan Abdul Hamid wedded three women of Sayyid extraction, viz. Syarifah Mariam, Syarifah Seha Sayyid Hussain Jamalullail and Syarifah Fatimah Sayyid Idris Shahabuddin. The handover of Kedah from Siam to British in 1909 strengthened the

\footnotetext{
34 Mohammad Redzuan Othman, "Conflicting Political Loyalties of the Arabs in Malaya before World War II," in Huub de Jonge and Nico Kaptein (eds.), Transcending Borders: Arabs, Politics, Trade and Islam in Southeast Asia (Leiden: KITLV Press, 2002), 38; Othman, "The Arabs Migration and Its Importance in the Historical Development of the Late Nineteenth and Early Twentieth Century Malaya," 17-19.

35 Sharifah Zaleha, "History and Indigenization of the Arabs in Kedah," 408.

36 The Jamalullail clan until today rules Perlis, located to the north of Kedah on the northwestern tip of Peninsular Malaysia bordering Thailand. Arau is Perlis' royal town.

37 Abdullah Zakaria bin Ghazali, "Sejarah Gerakan Politik Awal di Kedah," http://www.sabrizain.org/malaya/library/gerakankedah.pdf, 2-8. There is no consensus though on the actual year of Syeikh Abdul Samad al-Palembani's death.
} 
Sayyids' position in politics, public administration and religious bureaucracy.

In 1935, on Sayyid Muhammad Shahabuddin's advice, Kedah introduced the post of Syeikhul Islam, whose inaugural holder was imported from Saudi Arabia. For a great part of its post-independent history, Kedah's Chief Ministership was held by Sayyids. ${ }^{38}$ The Shahabuddin, al-Mashoor, al-Barak bah and al-Aidid families became the backbone of the ruling United Malays National Organisation (UMNO) chapter in Kedah. Tunku Abdul Rahman Putra Al-Haj (1903-1990AD.). UMNO's second President who became Malaysia's first Prime Minister, was the twentieth offspring of Sultan Abdul Hamid Halim Syah. Tunku himself married Syarifah Rodziah Sayyid Alwi al-Barakbah (1939-1990AD.). The acceptance of Sayyids as Malays was practically accomplished by the time Malaya achieved independence on 31 August 1957. Any vestige of relationship which the Sayyids maintained with Hadramaut, if at all, was for emotional rather than substantive purposes. ${ }^{39}$

In Penang, the first British trading post in Malaya, its pioneering colonial-settler Captain Francis Light had recognized the commanding influence of Tengku Sayyid Hussain al-Aidid, a Malay 'of Arab extraction' who had migrated from Aceh in 1792AD. Tengku Sayyid Hussain earned the distinction as the wealthiest man in Penang, and was said to have been installed as the Sultan of Aceh, albeit for only three days, after financing a local rebellion there. ${ }^{40}$ Since the end of the eighteenth century, Penang had emerged as the main port along the Straits of Malacca, with close trading networks with Aceh. ${ }^{41}$ The so-called Malay community of Acheen Street thrived on the spice trade. ${ }^{42}$ When this spice trade declined as a result of the

\footnotetext{
38 Sharifah Zaleha, "History and Indigenization of the Arabs in Kedah," 405-412; Othman, "The Arabs Migration and Its Importance in the Historical Development of the Late Nineteenth and Early Twentieth Century Malaya," 14-16.

${ }^{39}$ Sharifah Zaleha, "History and Indigenization of the Arabs in Kedah," 418-420.

40 Omar b. Yusoff, "Pengkisahan Melayu Pulau Pinang: Sesi Sejarah Lisan" [Penang Malay Narratives: Oral History Session], http://www.penangstory.net.my/bmcontent-paperomar.html, 25 August 2001; Lubis, "Traders, Teachers, Pressmen and Pilgrim Brokers: Penang Arabs in the Regional Network," 3-13.

41 Nordin Hussin, "Networks of Malay Merchants and the Rise of Penang as a Regional Trading Centre," Southeast Asian Studies 43, no. 3 (2005), 215-237.

42 Acheen Street was also popularly known as Jalan Masjid Melayu (Malay Mosque street). It is today located in the area of George Town, capital city of Penang, recognised by the United Nations Educational, Scientific and Cultural Organisation
} 
Dutch siege on Aceh, the economy of Acheen Street shifted emphasis to pilgrim sea transport to Jeddah. Up till the 1960s, the pilgrimage industry was controlled by hajj shaykhs, a disproportionate number of whom were Sayyids. ${ }^{43}$

Capitalizing on their economic prowess, Sayyids in Penang also dominated the fields of Islamic education and publications. A wellknown benefactor among the Sayyids was Sayyid Ahmad al-Mashoor, son-in-law of Penang's first mufti Syeikh Zakaria Basheer (18551926AD.). Sayyid Ahmad al-Mashoor gave his name to the famous Madrasah al-Mashoor, founded in 1918 as a reformist Islamic school. Madrasah Al-Mashoor was responsible for educating such prominent Malay nationalists as Dr. Burhanuddin Al-Helmy (1911-1969AD.), who was himself the offspring of a Malay. Arab marriage between Haji Muhammad Noor and Syarifah Zaharah. ${ }^{44}$ Another renowned Malay nationalist and literary figure, Sayyid Syeikh Ahmad al-Hadi (1867-1934AD), helmed both the Madrasah al-Mashoor and Jelutong Press, founded in 1927 as the hub of reformist-based Islamic publishing nativity in Penang ${ }^{45}$

In the northeastern state of Terengganu, members of the Malay ruling house have historically inter-married with Sayyid families whose patriarchs constantly counseled them. For example, Sultan Zainal Abidin I (reigned 1725-1734AD.) was guided by Syeikh Abdul Malik bin Syarif Abdullah (1650-1736AD.), better known as Tokku Pulau Manis. More than a century later, Sultan Zainal Abidin III's reign (1881-1918AD.) was propped up by Chief Minister Sayyid Abdullah and advised by Sayyid Abdul Rahman bin Muhammad Al-Idrus

(UNESCO) for conservation purposes. For a brief history, see "Influential Muslim Leaders in Penang," http://www.penangheritagecity.com/influential-muslimleaders.html

43 Aiza Maslan Baharudin, "Aktiviti Haji dan Perkembangan Pentadbirannya di Pulau Pinang" [Hajj Activities and its Administrative Development in Penang], paper presented at the 'Penang and the Hajj' Conference, E \& O Hotel, Penang, Malaysia, 17-18 August 2013.

${ }^{44}$ Dr. Burhanuddin was President of the Islamic Party of Malaysia (PAS: Parti Islam SeMalaysia, known prior to 1963 as the Pan-Malayan Islamic Party: PMIP) from 1956 until his death 1969. See Kamarudin Jaffar, Dr. Burbanuddin Al Helmy: Politik Melayu dan Islam (Kuala Lumpur: Yayasan Anda, 1980), 4.

45 Othman, "The Arabs Migration and Its Importance in the Historical Development of the Late Nineteenth and Early Twentieth Century Malaya", 12-13; Lubis, "Traders, Teachers, Pressmen and Pilgrim Brokers: Penang Arabs in the Regional Network," 36-39, 46-55. 
(1817-1917AD), who famously went by the nom de guerre of Tokku Paloh. Many influential Sayyids, now matrimonially related to the royalty, were granted administrative districts which enjoyed autonomous powers.

Under Tokku Paloh, the district of Paloh was administered under Syariah law. British documents have acknowledged the role of Tokku Paloh, mentioned as 'a fanatical holy man' by the name of 'Engku Sayyid', in protecting the absconding Pahang anti-colonial fighters, viz. Dato' Bahaman, Tok Gajah and his son Mat Kilau. As chief negotiator for the Terengganu government, Tokku Paloh had withstood enormous pressure from Hugh Clifford (1866-1941AD.), head of the British delegation demanding surrender of the insurgents. Under the powerful sway of Islam, Terengganu did not receive a British Resident until all other Malay states had. The British resorted to force to subdue the Terengganu Malay-Muslims, who were led by Tokku Paloh's student Haji Abdul Rahman Limbong (18681929AD.). Until today, Tokku Paloh's grandson, Sayyid Umar bin Sayyid Abdul Kadir al-Idrus (b. 1942AD.) still advises the Terengganu ruling house, even becoming Acting Sultan for a brief period in September October $2000{ }^{46}$

In the southernmost Malay state of Johore, Sayyids gained the trust of Sultan Abu Bakar (reigned 1862-1895AD.), acknowledged as the Father of Modern Johore. In 1863AD, the Sultan granted tin mining concessions in Ayer Puteh to Sayyid Abdullah Umar al-Junaid, Sayyid Junaid Umar al Junaid, Sayyid Abu Bakar Umar al-Junaid and Sayyid Salim Mohsin al-Attas. In 1878, Sayyid Muhamed Ahmad Abdul Rahman al-Sagoff was is turn awarded an agricultural land concession in Kukup, to which a land mining concession followed suit in 1889. Sayyid Muhamed not only acted as Sultan Abu Bakar's business agent and financial manager, but he also built linkages with the Ottoman Sultan Abdul Hamid II (reigned 1876-1909 AD.), who conferred him with the Ottoman Order medal for his services as its Honorary Consul General in Singapore Through the al-Sagoff \& Co. company, the al-Sagoff family dominated the shipping industry connecting Singapore, Muar and Malacon, monopolizing pilgrim transportation plying the Singapore-Mecca route. Among the

\footnotetext{
46 W. Linehan, "A History of Pahang," Journal of the Malayan Branch of the Royal Asiatic Society XIV, no. 2 (1936), 161-168; Abdul Ghani Said, 7 Wali Melayu (Kuala Lumpur: Penerbitan Hikmah, 1993), 28-54.
} 
beneficiaries were thousands of Javanese pilgrims who upon failure to defray their travelling costs, were bonded into contractual labor in alSagoff's agricultural farms.

At its peak, the al-Sagoff Concession Kukup as called by the British or Constantinople Estate as Sayyid Muhamed named it, measured fifty to sixty acres in size covering fourteen miles per square. It boasted a variety of vegetables and fruits, and was rented out to foreign companies to maximize revenue. Upon Sayyid Muhamed's death in 1906, Sayyid Abdul Kadir Abdul Rahman alSagoff and Sayyid Umar Muhamed al-Sagoff managed the deceased's assets and business. ${ }^{47}$

In both Johore and neighboring Singapore, as a matter of strategy, the wealthy Sayyids refrained from direct confrontation with the colonial government. As a Straits Settlement directly administered from London, Singapore bore the distinction of being the pivot of economic and socio-religious activities of the Arab diaspora in Southeast Asia. ${ }^{48}$ The relative peace that prevailed enabled the Sayyids to exploit their enormous wealth towards funding Islamic printing presses and schools, thus sowing the seeds of Malay nationalism. ${ }^{49}$

The al-Sagoffs, for instance, sponsored the anti-colonial newspaper Warta Malaya (1931-1941 AD.), mouthpiece of the Kesatuan Melayu Muda (K.MM: Young Malays' Union) led by the radical Ibrahim Yaakob (1910-1979AD.). Dragged into 'natural' leadership positions of the Malay society of post-Second World War Singapore, Hadrami Sayyids shouldered the responsibility of defending Malay identity. ${ }^{50}$ In an international conference to discuss the future of the post-Ottoman Islamic caliphate in Cairo in May 1926, Sayyid Muhammad Aqil represented Singapore, while Sayyid Hassan al-Attas and Sayyid Abu Bakar al-Attas acted as envoys of the Sultan of Johore. These Sayyids, frowned upon for allegedly

47 Mohd. Sohaimi Esa, "Ekonomi Orang Arab Johor pada Abad ke-19 Masihi hingga tahun 1914," Jebat: Malaysian Journal of History, Politics, and Strategic Studies 26 (1999), 58-59.

48 Bajunid, "The Arabs in Southeast Asia: A Preliminary Overview," 31; Othman, "Conflicting Political Loyalties of the Arabs in Malaya before World War II," 42.

49 William R. Roff, The Origins of Malay Nationalism (New Haven: Yale University Press, 1967), 41.

50 Syed Muhd Khairudin Aljunied, "The Role of Hadramis in Post-Second World War Singapore: A Reinterpretation”, Immigrants and Minorities 25, no. 2 (2007), 163 183. 
harboring connections with the pan-Islamist cause, had to weather constant spying on them by colonial agents. ${ }^{51}$

Sayyid Hassan al-Attas, a jewelry entrepreneur who was awarded mining concessions by Sultan Ahmad of Pahang in recognition of his role as mediator to solve the Pahang civil war (1857-1863AD.), had relocated to Johore by the end of the nineteenth century. ${ }^{52}$ In 1923, Sayyid Hassan established the Madrasah Al-Attas in Pekan, Pahang's royal town, ${ }^{53}$ and in 1927, he sponsored the founding of the Kulliyah al-Attas in Johor Baharu, led by the AlAzhar educated Syeikh Muhammad Fadhlullah as-Suhaimi (18861964AD.). ${ }^{54}$ In 1936 Syeikh Muhammad Fadhlullah founded the Madrasah al-Ma'arif in Tanjung Katong, Singapore. Madrasah alMa'arif gained renown for being at the forefront of Islamic reformism in Singapore, pioneering for instance formal female education, the teaching of English language as a subject alongside Arabic and Malay, a modern curriculum which incorporated instructions of subjects hitherto thought of as "secular", the changing of weekend holidays from Fridays to Sundays, the streamlining of term holidays with the public schools' calendar, and the charging of school fees. ${ }^{55}$ As a prolific scholar, Syeikh Muhammad Fadhlullah advocated the unification of religious administrations of Malay states, led the delegation from Kelantan to the Malay Congress which formed

\footnotetext{
51 Othman, "Conflicting Political Loyalties of the Arabs in Malaya before World War II," 47-50.

52 Mohd. Sohaimi, "Ekonomi Orang Arab Johor pada abad ke-19 Masihi hingga tahun 1914," 47-48.

53 Othman, "The Arabs Migration and Its Importance in the Historical Development of the Late Nineteenth and Early Twentieth Century Malaya," 12.

54 Ni'mah bt $\mathrm{Hj}$ Ismail Umar, Fadblullah Subaimi (Ulu Kelang: Progressive Publishing House, 1998), 20.

55 Syed Muhd Khairudin Aljunied and Dayang Istiaisyah Hussin, "Estranged from the Ideal Past: Historical Evolution of Madrassahs in Singapore," Journal of Muslim Minority Affairs 25, no. 2 (2005), 253.
} 
UMNO in $1946 .{ }^{56}$ and chaired ulama conferences, one of which eventually led to the formation of PAS. ${ }^{57}$

Syeikh Muhammad Fadhlullah was the son of another prominent Sayyid, Sayyidi Syeikh Muhammad bin Abdullah asSuhaimi (1843-1925AD.) or Syeikh Suhaimi, who hailed from Wonosobo, Central Java, but led a long distinguished career as prayercum-community leader of the Ma'ruf Mosque, Singapore, before settling down in Teluk Pulai, Kelang, Selangor, in 1900. Syeikh Suhaimi was a peripatetic sufi who constantly traveled back and forth between Malaya and Singapore, even marrying a Penang lass by the name of Salbiah who died giving birth to her eldest child in $1911 .^{58}$

Syeikh Suhaimi drew students from across Southeast Asia, but was especially popular among the Javanese-Arab communities residing along with littoral settlements of western Malay Peninsula. ${ }^{59}$ Honored by his disciples with the title of Kiyai Agung, meaning 'Great Religious Teacher', Syeikh Suhaimi instilled spiritual discipline into his expanding congregation by training them at first with practices of the 'Alawiyya and Ghazâliyya tariqahs, ${ }^{60}$ and later inducting them into a new order called the Aurad Muhammadiah, whose epistle he claimed

56 Syeikh Muhammad Fadhlullah was mostly based in Kelantan during the Japanese occupation of Malaya (1942-1945) and early post-war years as controller and headmaster in the Islamic educational system run by its Council of Islamic Religion and Malay Custom (MAIK: Majlis Agama dan Adat Istiadat Melayu Kelantan); see Abdullah Alwi Haji Hassan, "The Development of Islamic Education in Kelantan," in Khoo Kay Kim (ed.), Tamadun Islam di Malaysia (Kuala Lumpur: Persatuan Sejarah Malaysia, 1980), 199-200; Ni'mah, Fadblullab Subaimi, 21.

${ }^{57}$ Safie bin Ibrahim, The Islamic Party of Malaysia: Its Formative Stages and Ideology (Pasir Puteh: Nuawi bin Ismail, 1981), 17-18; Mokhtar Petah, Sheikh Abdullah Fabim: Penentu Tarikh Kemerdekaan Negara 31 Ogos 1957 (Kuala Lumpur: Pustaka Antara, 1997), 9; Mohd Fadli Ghani, "Sheikh Fadhlullah As-Suhaimi: Ulama pengasas PAS."

58 The present authors thank Malaysia's Keepers of the Rulers' Seal, Dato' Syed Danial Syed Ahmad, for emailing on 9 March 2011 a digitally scanned copy of Syeikh Suhaimi's letter to his in-laws in Penang, dated 4 Zulqaedah 1329H., equivalent to 26 October 1911AD.

59 Ustadz Hj. Mohd Taha Suhaimi, Sejarah Hidup Syeikh Mubammad Subaimi (Singapore: PERIPENSIS, 1990), 23, 34-43.

60 Ustaz Hj. Muhammad Taha Suhaimi, Tiada Tengkarah Mengenai Aurad Mubammadiah: Jawapan- jawapan kepada Ustaz Hj. Abu Bakar Hashim, Prof. Dr. Harun Din, Hj. Ashaari Muhammad, Majlis Pusat Islam, Kuala Lumpur (Singapore: PERIPENSIS, 1994), 21-22; Muhammad bin Abdullah As Suhaimi, Hembusan Kasturi: Maulid Nabi SAW, translated by Muhammad Taha Suhaimi (Singapore: PERIPENSIS, fourth edition, 1995), 1. 
to have obtained directly from the Prophet Muhammad via spiritual communication - a claim which remains controversial to this day. ${ }^{61}$

Another noteworthy Sayyid of colonial Singapore was Sayyid Nuh bin Sayyid Mohamad bin Sayyid Ahmad al-Habsyi, popularly known as Habib Nuh (1788-1866AD.). Habib Nuh was born on board of a vessel on the way from Palembang to Penang, where his father served as officer of the colonial government. He moved to Singapore around 1819 on the invitation of Habib Salim bin Abdullah Sumayr, a Hadrami follower of the Naqshbandiyya sufi order. ${ }^{62}$

Paradoxically, his methodology of dawah utilized unconventional means: an eccentric lifestyle, avuncular counsels to local MalayMuslims and saintly miracles. ${ }^{63}$ Held in awe by British colonial officials, he was jailed a few times, only to end up converting four English prison officers to Islam. All four of them attended his funeral, as reported by The Singapore Free Press dated 2 August 1866. He advised a visitor, Haji Said from Besut, Terengganu, to send his children for religious classes with Sayyid Abdurrahman, i.e., Tokku Paloh, hence testifying to his regional outreach. Still even more peculiar, Habib Nuh was reported to have enjoyed watching Chinese opera performances on the invitation of the Buddhist priest from the temple near his hermitage atop Mount Palmer, Tanjung Pagar, where his tomb is located today. ${ }^{64}$ Laid to rest far away from other Muslim cemeteries, his grave is frequented till today by visitors of various ethnoreligious backgrounds. ${ }^{65}$ Habib Nuh's life demonstrates the feasibility of reconciling intense Islamic religiosity with harmonious racial relations - a pre-requisite of nation-building in post-colonial Southeast Asia.

In contemporary Malaysia, history repeats itself at the hands of millionaire tycoon Sayyid Mokhtar al-Bukhary (b. 1951AD.). Currently, the richest Malay-Muslim, Sayyid Mokhtar, through his Al-

${ }^{61}$ Ahmad Fauzi Abdul Hamid, "The Aurad Muhammadiah Congregation: Modern Transnational Sufism in Southeast Asia", in Hui Yew-Foong (ed.), Encountering Islam: The Politics of Religious Identities in Southeast Asia (Singapore: Institute of Southeast Asian Studies, 2013), 72-74.

${ }^{62}$ Muhammad Ghouse Khan Surattee, The Grand Saint of Singapore: The Life of Habib Nub bin Muhammad al-Habshi (Singapore: Masjid al-Firdaus, 2008), 30-33.

${ }^{63}$ Said, 7 Wali Melayu, 16-26.

${ }^{64}$ Muhammad Ghouse, The Grand Saint of Singapore, 34, 46-55.

65 Burhanuddin al-Helmi, Simposium Tasawnf dan Tarikat (Ipoh: Pustaka Muda, 2005), 66. 
Bukhary Foundation, has sponsored many large-scale Islamic projects such as the Islamic Arts Museum in Kuala Lumpur and the AlBukhary International University in his native Alor Setar, Kedah. ${ }^{66}$ His business skill emulates the style of Sayyids during colonial times, when they exploited to the full their close relationship with the Malay sultans and modus vivendi with the colonial authorities. Sayyid Mokhtar, in comparison, had benefited enormously from government patronage, particularly during the Premiership of Dr. Mahathir Mohamad (1981- 2003AD.). In politics, indigenized Sayyids inherited spellbinding skills in negotiation and diplomacy from their forefathers. ${ }^{67}$

This advantage earned them important positions alongside traditional Malay elites, and in time becoming part of them. Sayyids traditionally excelled in their role as the ambassadors of sultans and now of the Malaysian government in Middle Easter and international Islamic affairs. Their intimacy with the Malay royalty is evidenced by their retention of the post of the Keeper of the Rulers' Seal in January 2011, at the hands of former bureaucrat Dato' Sayyid Danial Sayyid Ahmad of Penang who replaced Terengganu's Engku Ibrahim Engku Ngah, originally Sayyid Muhammad al-Idrus, after the latter's tenure of twenty-two years. ${ }^{68}$

\section{Concluding Remarks}

This article has provided an overview of the process of Islamization as spearheaded by the Sayyids in regions of the Malay world that today form modern Malaysia and Singapore. Examples were taken from the activities of Sayyids in the states of Kedah, Penang, Terengganu, Johore and Singapore during colonial times. Singapore gained independence inside the Malaysian federation in 1963 but split to form a sovereign nation-state in 1965. Although Sayyids were most active in these states, their presence could be found throughout British Malaya.

\footnotetext{
${ }^{66}$ For background information on Tan Sri Syed Mokhtar al-Bukhary and his alBukhary Foundation's projects, see Razak Ahmad, "Tan Sri Syed Mokhtar Albukhary - Tycoon lives by a moral compas," The Sunday Star, 25 November 2012.

${ }^{67}$ Cf. Kostiner, "The Impact of Hadrami Emigrants in the East Indies on Islamic Modernism and Social Change in the Hadramawt during the 20th Century," 221 222.

${ }^{68}$ Information on Engku Ibrahim Engku Ngah was emailed by Dato' Syed Danial Syed Ahmad to the first author on 9 March 2011.
} 
The fact that they embraced sufi-inclined notions of da'wah is most relevant in explaining their success in the Malay world. The observation made by Professor A.H. Johns for Java more than half a century ago arguably still holds today for the Malay world generally: "a characteristic of the Sufi Apostolate was a readiness to build on the past and to enroll elements of local belief and custom into the service of Islam .... it can be fairly asserted that an Islam of the Wabhabi type would have made little impact on Java for the same reasons as the modernist Masjumi party, spiritual descendant of the Wabhabis, has been a comparative failure there." 69

As a consequence of the leading roles played by the Sayyids in facing the challenge of Western colonialism in the Malay world, Islamization in Malaya and Singapore was almost free from violence. Even though armed conflict did take place, the anti-colonial struggle was colored by subtler challenges in the economic and educational fields. The exception was when large demonstrations became indispensable, as during UMNO's fight against the British-sponsored Malayan Union scheme in 1946. The history of Sayyids in the Middle East is replete with examples of how they reacted as a community to persecution not through violence but rather through migration and persistent efforts at negotiation. The moving culture of the Sayyids demanded economic strength, which they successfully combined with an extraordinary spirit of da'wah in their quotidian activities.

Propagating Islam was never separated from their daily routines, in fact they lived and prospered on the Islamic mission. In this vocation, they did not rely merely on oral propagation (lisan almaqā ), but rather focused on becoming exemplary characters in their social and economic lives-a form of lisän al-häl. Their astounding industry and acumen in business was an extremely effective method of spreading Islam to the Malays. Who had been projected by the colonialists as lazy and lack the competitive spirit vis-à-vis migrants, whom the British imported into Malaya out of economic considerations.

\section{Bibliography}

Abdullah, Wan Mohd. Shaghir. Penyebaran Thariqat-thariqat Shufiyah Mu'tabarah di Dunia Melayu. Kuala Lumpur: Khazanah Fathaniyah, 2000.

${ }^{69}$ Johns, "Sufism as a Category in Indonesian Literature and History," 19. 
Ahmad, Razak. "Tan Sri Syed Mokhtar Albukhary - Tycoon Lives by a Moral Compas," The Sunday Star, 25 November 2012.

al-Attas, Syed Muhammad Naquib. Historical Fact and Fiction. Johor Bahru: Universiti Teknologi Malaysia Press, 2012.

al-Attas, Syed Naguib. Preliminary Statement on a General Theory of the Islamisation of the Malay-Indonesian Archipelago. Kuala Lumpur: Dewan Bahasa dan Pustaka, 1969.

-----. Some Aspects of Sufism as Understood and Practised among the Malays (edited by Shirle Gordon). Singapore: Malaysian Sociological Research Institute, 1963.

al-Helmi, Burhanuddin. Simposium Tasawnf dan Tarikat. Ipoh: Pustaka Muda, 2005.

Alatas, Syed Farid. "Notes on Various Theories Regarding the Islamisation of the Malay Archipelago," The Muslim World LXXV, nos. 3-4, 1985.

----. "The Tariqat al-'Alawiyyah and the Emergence of the Shi' School in Indonesia and Malaysia," Oriente Moderno, XVIII (LXXIX), 1999.

-----. Al-Husain bin Ali r.a. sebagai Sumber Ciri-ciri Manusia Baru. Singapore: Masjid Ba'alwi, 2009.

Alatas, Syed Hussein. "On the Need for an Historical Study of Malaysian Islamisation," Journal of Southeast Asian History 4, no. 3, 1963.

----. "The Weber Thesis and South East Asia," Archives De Sociologie Des Religions 15, 1963.

Aljunied, Syed Muhd Khairudin and Hussin, Dayang Istiaisyah. "Estranged from the Ideal Past: Historical Evolution of Madrassahs in Singapore," Journal of Muslim Minority Affairs 25, no. 2, 2005.

Aljunied, Syed Muhd Khairudin. "The Role of Hadramis in PostSecond World War Singapore: A Reinterpretation", Immigrants and Minorities 25, no. 2, 2007.

Anwar, Zainah. Islamic Revivalism in Malaysia: Dakwah among the Students. Petaling Jaya: Pelanduk Publications, 1987.

Baharudin, Aiza Maslan. "Aktiviti Haji dan Perkembangan Pentadbirannya di Pulau Pinang" [Hajj Activities and its Administrative Development in Penang], paper presented at the 'Penang and the Hajj' Conference, E \& O Hotel, Penang, Malaysia, 17-18 August 2013. 
Bajunid, Omar Farouk. "The Arabs in Southeast Asia: A Preliminary Overview," Hiroshima Journal of International Studies 8, 1996.

Bakar, Osman. "Sufism in the Malay-Indonesian World," in Seyyed Hossein Nasr (ed.), Islamic Spirituality: Manifestations. London: SCM Press, 1991.

Coatalen, Paul. "The Coming of Islam to S.E. Asia: A Critical Review of Some Extant Theories," The Islamic Quarterly XXV, nos. 3-4, 1981.

Esa, Mohd. Sohaimi. "Ekonomi Orang Arab Johor pada Abad ke-19 Masihi hingga tahun 1914," Jebat: Malaysian Journal of History, Politics, and Strategic Studies 26, 1999.

Fatimi, Cf. S.Q. Islam Comes to Malaysia (edited by Shirle Gordon). Singapore: Malaysian Sociological Research Institute, 1963.

Ghazali, Abdullah Zakaria bin. "Sejarah Gerakan Politik Awal di Kedah,” http://www.sabrizain.org/malaya/library/gerakan kedah.pdf.

Hamid, Ahmad Fauzi Abdul. "The Aurad Muhammadiah Congregation: Modern Transnational Sufism in Southeast Asia", in Hui Yew-Foong (ed.), Encountering Islam: The Politics of Religious Identities in Southeast Asia. Singapore: Institute of Southeast Asian Studies, 2013.

----. "The Impact of Sufism on Muslims in Pre-colonial Malaysia: An Overview of Interpretations," Islamic Studies 41, no. 3, 2002.

Hassan, Abdullah Alwi Haji. "The Development of Islamic Education in Kelantan," in Khoo Kay Kim (ed.), Tamadun Islam di Malaysia. Kuala Lumpur: Persatuan Sejarah Malaysia, 1980.

Hassan, Sharifah Zaleha binti Syed. "Negotiating Islamism: The Experiences of the Muslim Youth Movement of Malaysia," Journal for Islamic Studies 29, 2009.

Hassan, Sharifah Zaleha Syed. "History and Indigenization of the Arabs in Kedah," Asian Journal of Social Science 32, no. 3, 2004.

Ibrahim, Safie bin. The Islamic Party of Malaysia: Its Formative Stages and Ideology. Pasir Puteh: Nuawi bin Ismail, 1981.

Ishak, Abdullah. Pendidikan Islam dan Pengarubnya di Malaysia. Kuala Lumpur: Dewan Bahasa dan Pustaka, 1995.

Jaffar, Kamarudin. Dr. Burbanuddin Al Helmy: Politik Melayu dan Islam. Kuala Lumpur: Yayasan Anda, 1980.

Johns, A.H. "Sufism as a Category in Indonesian Literature and History," Journal of Southeast Asian History 2, no. 2, 1961. 
-----. "The Role of Sufism in the Spread of Islam to Malaya and Indonesia," Journal of the Pakistan Historical Society 9, no. 3, 1961.

----. "Islamisation in Southeast Asia: Reflections and Reconsiderations with Special Reference to the Role of Sufism," Southeast Asian Studies 31, no. 1, 1993.

Kathir, Ibn. The Signs Before the Day of Judgement (translated by Huda Khattab). London: Dar Al Taqwa, 1991.

Kostiner, Joseph. "The Impact of Hadrami Emigrants in the East Indies on Islamic Modernism and Social Change in the Hadramawt during the $20^{\text {th }}$ Century', in Raphael Israeli and Anthony H. Johns (eds.), Islam in Asia: Volume II Southeast Asia and East Asia. Jerusalem: The Magnes Press, 1984.

Linehan, W. "A History of Pahang," Journal of the Malayan Branch of the Royal Asiatic Society XIV, no. 2, 1936.

Lubis, Abdur-Razzaq. "Traders, Teachers, Pressmen and Pilgrim Brokers: Penang Arabs in the Regional Network," paper presented at the Conference 'Rihlah - Arabs in Southeast Asia', National Library, Singapore, 10-11 April 2011.

Marrison, G.E. "The Coming of Islam to the East Indies," Journal of the Malayan Branch of the Royal Asiatic Society XXIV, no. 1, 1951.

Mauladdawilah, Abdul Qadir Umar. Tarim: Kota Sejuta Wali. Kuala Lumpur: InTeam Publishing, 2014.

Nagata, Judith A. The Reflowering of Malaysian Islam: Modern Religious Radicals and their Roots. Vancouver: University of British Columbia Press, 1984.

Nordin Hussin, "Networks of Malay Merchants and the Rise of Penang as a Regional Trading Centre," Southeast Asian Studies 43, no. 3, 2005.

Othman, (Tun) Suzana (Tun) Hj and Mohamad, Hj Muzaffar Dato' Hj. Ablul-Bait (Keluarga) Rasulullah SAW \& Kesultanan Melayu. Batu Caves: Crescent News, 2006.

Othman, Mohammad Redzuan. "Conflicting Political Loyalties of the Arabs in Malaya before World War II," in Huub de Jonge and Nico Kaptein (eds.), Transcending Borders: Arabs, Politics, Trade and Islam in Southeast Asia. Leiden: KITLV Press, 2002.

"The Arabs Migration and Its Importance in the Historical Development of the Late Nineteenth and Early Twentieth Century Malaya," paper presented at the $15^{\text {th }}$ Annual 
Conference of the World History Association, California State University, Los Angeles, USA, 22-25 June 2006.

Petah, Mokhtar. Sheikh Abdullah Fabim: Penentu Tarikh Kemerdekaan Negara 31 Ogos 1957. Kuala Lumpur: Pustaka Antara, 1997.

Roff, William R. The Origins of Malay Nationalism. New Haven: Yale University Press, 1967.

Said, Abdul Ghani. 7 Wali Melayu. Kuala Lumpur: Penerbitan Hikmah, 1993.

Shamsul, A.B. "A History of an Identity, an Identity of a History: The Idea and Practice of 'Malayness' in Malaysia Reconsidered," Journal of Southeast Asian Studies 32, no. 3, 2001.

Suhaimi, Muhammad bin Abdullah As. Hembusan Kasturi: Maulid Nabi $S A W$, translated by Muhammad Taha Suhaimi. Singapore: PERIPENSIS, fourth edition, 1995.

Suhaimi, Ustadz Hj. Mohd Taha. Sejarah Hidup Syeikh Muhammad Subaimi. Singapore: PERIPENSIS, 1990.

Suhaimi, Ustaz Hj. Muhammad Taha. Tiada Tengkarah Mengenai Aurad Muhammadiah: Jawapan- jawapan kepada Ustaz. Hj. Abu Bakar Hashim, Prof. Dr. Harun Din, Hj. Ashaari Mubammad, Majlis Pusat Islam, Kuala Lumpur. Singapore: PERIPENSIS, 1994.

Surattee, Muhammad Ghouse Khan. The Grand Saint of Singapore: The Life of Habib Nub bin Mubammad al-Habshi. Singapore: Masjid alFirdaus, 2008.

Tibbetts, G.R. "Early Muslim Traders in South-East Asia," Journal of the Malayan Branch of the Royal Asiatic Society XXX, no. 1, 1957.

Umar, Ni'mah bt $\mathrm{Hj}$ Ismail. Fadblullah Subaimi. Ulu Kelang: Progressive Publishing House, 1998.

Yahaya, Mahayudin Haji. "Latarbelakang Sejarah Keturunan Sayid di Malaysia," in Khoo Kay Kim (ed.), Tamadun Islam di Malaysia. Kuala Lumpur: Persatuan Sejarah Malaysia, 1980.

Yuanzhi, Kong. Pelayaran Zheng He dan Alam Melayu. Bangi: Penerbit Universiti Kebangsaan Malaysia, 2000.

Yusoff, Omar b. "Pengkisahan Melayu Pulau Pinang: Sesi Sejarah Lisan" [Penang Malay Narratives: Oral History Session], http:/ / www.penangstory.net.my/bm-content-paperomar.html, 25 August 2001. 